UDC $336.7(100)+339.732 .6$

DOI $10.33111 /$ iep.2020.32_33.06_eng

\title{
Formation of the Concept of Risk-Oriented Banking Supervision in Central and Eastern Europe \\ Oleh Mozhovyi ${ }^{1}$,
Olena PaVliuk
}

ABSTRACT. The banking supervision system is an evolutionary process of overseeing the implementation of regulatory initiatives based on the corporate principles of BCBS banking supervision and include initiatives of international financial supervisors and the world's leading banks on: risk-weighing of assets; regulation of systemically important banks; conduction of macroprudential and relevant microprudential policy; risk management strategies; recovery planning and troubleshooting. The formation of the banking supervision system of Central and Eastern Europe takes place under the auspices of leading European countries and around the principles of EU banking systems for risk regulation and control. The article analyzes the banking supervision initiatives of leading financial institutions and their role in the development of banking supervision systems in Central and Eastern Europe, which is the development of harmonized approaches in the field of banking supervision at national and international levels, control over comparability of capital adequacy, liquidity and the implementation of new regulatory requirements. The global institutional foundations of global banking supervision have been summarized and the role of the Basel Committee on Banking Supervision in global banking regulation and supervision practices has been defined. The current trends of banking supervision under the leadership of the Basel Committee on Banking Supervision, in particular - modern approaches for assessment of bank capital adequacy, liquidity regulation, regulation of systemically important banks and stress testing policy as a modern element of risk management practice have been analyzed. The methodological principles of the approach to the formation of risk-oriented banking supervision technologies, which is a concept of three main components (minimum capital requirements, supervision procedure, market discipline) and contributes to the spread of more reliable risk management practices in banks, have been analyzed. Therefore, the main purposes of the article are characterization of the main elements of the banking supervision system of CEE countries and identification of indicative banking supervision areas for these countries in the process of risk formation. The main approaches of banking supervision for the evaluation of credit risks in Ukraine, in comparison with the approaches of world financial organizations (Basel Committee) and leading European banks, have been analyzed. The analysis of the imperatives of banking supervision in Ukraine has been conducted and the directions for its reform have been shown in accordance with the comprehensive program for the development of the financial sector of Ukraine until 2020 with the help of the implementation of the requirements of banking supervision of the EU countries. The analysis of compliance of

\footnotetext{
* The article was translated from its original in Ukrainian.

1 Mozhovyi Oleh Mykolaiovych - Doctor of Economics, Professor, Member of the International Slavic Academy of Sciences, Head of the International Finance Department of Kyiv National Economic University named after Vadym Hetman. Awarded with the Order of Merit of the $2^{\text {nd }}$ and $3^{\text {rd }}$ degrees, Honorary Certificates of the Cabinet of Ministers of Ukraine and Verkhovna Rada, holds the honorary title "Honored Economist of Ukraine" and $1^{\text {st }}$ rank of public servant. Member of the Union of Economists of Ukraine. Author of 120 scientific, research and methodological works. Sphere of scientific interest: international finance, global regulation of financial markets, global market of securities, regulatory policy and global development of stock markets, national financial systems. E-mail: meo410@kiev.kneu.ua

2 Pavliuk Olena Oleksandrivna - Doctor of Economics, Associate Professor of the International Finance Department of Kyiv National Economic University named after Vadym Hetman. Sphere of scientific interest: international banking, bank supervision and regulation, bank supervision in Ukraine. E-mail: elena_pavluk@ukr.net
}

IEP, No. 32-33, (2020) pp. 139-155

(C) Oleh Mozhovyi, Olena Pavliuk, 2020 «All rights reserved»

ISSN 1811-9832/2020/ No. 1-2 (32-33) 
banking supervision of Ukraine with the world's advanced methods of banking supervision and regulation has been carried out. The necessity of improvement of the banking supervision system in Ukraine and introduction of a risk-based approach in banking supervision have been substantiated.

KEY WORDS: Banking supervision and regulation of Central and Eastern European countries, regulatory banking environment, banking risks, Basel Committee on Banking Supervision, capital adequacy.

\section{Introduction}

In 2010, the Basel Committee published the Third Basel Accord ${ }^{3}$, which is a key regulatory document aimed at improvement of the quality of risk and capital management of financial institutions. This document establishes new minimum capital requirements, new liquidity and leverage indicators, as well as new methods and approaches to risk measurement and evaluation. In addition, the document introduces stricter standards for supervision of banking activities, as well as increased requirements for information disclosure and risk management. There is noted that banking regulation has never had such a high profile and has never been so important as it is today in one of the latest studies by Putnis $J$. on banking supervision. The subject of banking regulation has affected the agenda as politicians have realized the damage that failed banks can do to the national and regional economy. Putnis J. states that national banks often face the problem of lack of portfolio supervision in all banks in their country and therefore potentially do not identify the concentration of risks in the banking system of the country ${ }^{4}$. According to J. Barth and J. Gan "regulation refers to a set of laws and regulations applicable to banking activities, and supervision is defined as monitoring the activities of banks and compliance with banking regulations» ${ }^{5}$. At the same time, they point out that the role of the banking business has changed and therefore the way banks are regulated and controlled has changed. The authors of the article "The Structure of Cross-Sector Financial Supervision" Herring and Karmasi analyze changes in banking supervision and focus on an integrated approach and show that crisis management may not be an adequate replacement for the traditional model in which prudential supervision is carried out within the central bank ${ }^{6}$. According to analysts of the audit company KPMG, the supervisory pressure most

\footnotetext{
${ }^{3}$ Basel Committee on Banking Supervision, Third Basel Accord. URL: http://www. bis.org. [In Ukrainian].

${ }^{4}$ Putnis J. The banking regulation review. London: The Lawreviews, 2017. 633 p.

${ }^{5}$ Global Banking Regulation \& Supervision: What Are the Issues and What Are the Practices? J. Barth, J. Gan, D. Nolle. 2003. URL: http://www.ckgsb.edu.cn/Userfiles/doc/BARTHnolle\%20gan_bood.pdf.

${ }^{6}$ Herring R. J., Carmassi J. The Structure of Cross-Sector Financial Supervision. Financial Markets, Institutions \& Instruments. 2008. No.1. pp. 51-76.
} 
affected the countries of Central and Eastern Europe, which are trying to get adequate profits and demonstrate that they have a viable and stable business regime. Asset withdrawals and balance sheet deficit risks push most banks to meet existing capital and liquidity regulations in the EU. Nevertheless, next to this, there are still problems that are associated with the profitability of banks, increased costs, which affects ensuring a stable future ${ }^{7}$. The authors of the article "Financial Supervision in Central and Eastern Europe" define banking supervision strategies, one of which is comprehensive supervision, the effectiveness of which is associated with the establishment and unification of procedures, which allows to reduce the cost of supervision and facilitate contacts with entities under supervision. There are also various forms of criticism against the integrated model, which, in their opinion, serves the interests of the multifunctional service of a financial group, they comment that by integrating all financial supervision in one supervisory body, the latter becomes too large, too unmanageable and too powerful ${ }^{8}$. Foreign scientific works on the formation of the regulatory environment of the European Union, as well as research on banking management, belong to Western practical analysts Timothy Koch and Scott MacDonald $^{9}$. Neuberger D. identifies competition policy in the banking sector as an additional group of supervisory banking measures and defines preventive supervision measures that are aimed at avoidance of bank bankruptcy. They cover requirements for equity, liquidity and diversification, provision of information, banning of certain types of banking operations and reporting instructions. This also includes licensing conditions that are crucial within the framework of supervision ${ }^{10}$. Borner C.J. believes that for this reason, discretionary regulation, which provides for a certain freedom of action both when initiating sanctions and choosing them, should be identified with qualitative regulation, which is associated with the method of risk (reason) evaluation ${ }^{11}$. According to V. Greuning, traditional banking analysis is based on quantitative methods for evaluation of the bank's condition, including relative indicators such as: liquidity ratios; capital adequacy ratio; quality of the loan portfolio; share of the loan provided to authorized and associated persons; credit risk of potential losses and open currency positions ${ }^{12}$. The banking supervision methodology of the

\footnotetext{
${ }^{7}$ Evolving Banking Regulation. KPMG International. 2015. URL: www.kpmg.com.

8 Wymeersh E. The structure of financial supervision in Europe: About single, twin peaks and multiple financial supervisors. European Business Organization Law Review. 2006. No.8. pp. 237-306.

9 Timothy W.Koch, MacDonald S.Scott. Bank management/W.K. Timothy,S.S.MacDonald.-,USA: Thomson Higher Education,2006.-562 p.

${ }^{10}$ Neuberger D. Mikroökonomik der Bank. München: Verlag Vahlen, 1998. 240 p.

11 Börner C.J. Treu und redlich? Eine explorative Bewertung qualitativer Bankenregulierung. Rektor der der Heinrich-Heine-Universität Düsseldorf (Hrsg.): Jahrbuch 2003. Duisburg, 2003. pp. 335-352. [In German].

12 Grüning H. Analysis of banking risks. System for assessing corporate governance and financial risk
} 
Basel Committee on Banking Supervision, which is implemented in the Second Basel Accord, is an example of popularization of indicative regulation instead of administrative regulation.

The analysis of literature sources devoted to the study of banking supervision in Central and Eastern Europe shows that the banking supervision system consists of such elements as: regulatory environment; availability of banking supervision institutions; established requirements of banking supervision in accordance with the development of the banking system (standards, indicators, coefficients, rules, licenses); forms of banking supervision. The elements of the banking supervision system are interrelated, as they work to achieve a common goal: analysis and risk management of banks and compliance with prudential norms of banking supervision; the main directions of development of European supervision remain the unification of European banking rules, which simplify the procedure for conducting banking supervision within the European Union; theoretical and practical issues of the ways of evolution of banking supervision in Central and Eastern Europe in the concept of a risk-based approach remain relevant. According to the law of Ukraine "On the National Bank of Ukraine" Art. 1 "Banking Supervision is a system of control and active orderly actions of the National Bank of Ukraine aimed at ensuring compliance by banks and other persons, in respect of whom the National Bank of Ukraine exercises supervisory activities, with the legislation of Ukraine and established standards, in order to ensure the stability of the banking system and protect the interests of depositors and creditors of the bank; banking regulation is one of the functions of the NBU, which is the creation of a system of norms regulating the activities of banks and characterization of the general principles of banking activities, the procedure for Banking Supervision and liability for violations of banking legislation"13. A similar definition of banking supervision is given by Article 67 of the law of Ukraine "On Banks and Banking activities". This article states that "the purpose of banking supervision is to ensure the stability of the banking system and protect the interests of depositors and creditors of the bank regarding the security of keeping customer funds in bank accounts"14. According to Article 4 of the Law of Ukraine "On Banks and Banking Activities", the National Bank of Ukraine regulates and supervises banking supervision in accordance with the provisions of the Constitution of Ukraine, this Law, the Law of

\footnotetext{
management / transl. from English. Moscow: Ves mir, 2007. - 304 p. [In Russian].

${ }_{13}$ On the National Bank of Ukraine: Law of Ukraine of May 20, 1999 No. 679-XIV. Information of the Verkhovna Rada of Ukraine. 1999. p. 238. [In Ukrainian].

14 On banks and banking activity: Law of Ukraine of December 7, 2000 No. 2121-III. Information of the Verkhovna Rada of Ukraine. 2001. - p. 30. [In Ukrainian].
} 
Ukraine "On the National Bank of Ukraine", other legislative acts of Ukraine and normative legal acts of the National Bank of Ukraine. The National Bank of Ukraine determines the specifics of regulation and supervision of a systemically important bank, a bank that has the status of a Settlement center for servicing contracts in financial markets, considering the specifics of the activities of such banks.

Domestic scientific approaches to the interpretation of banking supervision generally adhere to the above-mentioned legislative provisions. Disagreements arise, first of all, when defining the essence of the concepts of banking regulation and supervision. In particular, in their textbook, V. Mishchenko and a number of other authors understand the regulation of banking activities as, first of all, the creation of an appropriate legal framework, that is, the development and adoption of laws regulating the activities of banks, as well as the adoption of provisions regulating the functioning of banks in the form of regulations, instructions, directives by relevant institutions authorized by the state. Legislative and regulatory provisions define the boundaries of bank behavior that would contribute to the reliable and efficient functioning of the banking system. Banking supervision is defined as "monitoring of the processes taking place in the banking sector at different stages of bank functioning, namely: creation of new banks and their institutions, activities of banks, reorganization and liquidation of banks. For this purpose, the supervisory authority has the authority to apply coercive and non-coercive measures of influence to banks"15.

\section{Concept of risk-based banking supervision}

Analysis of research on banking regulation and supervision shows that these are interrelated concepts that have several important components. First of all, they are mandatory rules for banks and banking groups to conduct banking operations, accounting and reporting, organize internal control, prepare and provide accounting and statistical reports. The second element is that these two interrelated processes establish special standards for banks' activities, which are aimed at limiting their risks and protection of the interests of customers and depositors, as well as society as a whole. These standards include: the minimum amount of regulatory capital; the standard of sufficiency (adequacy) of regulatory capital; the standard of the ratio of regulatory capital to the bank's liabilities; liquidity standards. The development of banking systems was carried out for quite a long time under the

\footnotetext{
${ }^{15}$ Banking supervision: textbook (ukr. Bankivskyi naglyad) / Mishchenko V. et al. Kyiv, 2004. - pp. 47-48. [In Ukrainian].
} 
influence of historical, economic and political factors, as well as legal and judicial practice.

Edward Kane describes the relationship between banking regulators and banks as a dialectic of regulation or a model of competition. His idea lies in the Hegelian concept, which consists of a three-stage structure of any process of change: the first stage is thesis; the second is antithesis; the third is synthesis. The collision of thesis and antithesis leads to synthesis. Synthesis then becomes a new thesis in the fight against the next antithesis that gives a new synthesis. In finance, the fight (competition) is also continuous, as regulation can be imagined as taxes that banks seek to avoid. The reason for this fight (competition) is the discrepancy between the goals set by regulators and banking structures. The goal of regulators is to maintain the security, stability and viable (competitive) financial system; the task of bankers is to increase the value of certain variables - capital, profit, etc. Banks are trying to overcome regulatory restrictions by trying to find ways to avoid implementation of regulations and laws. In response, the supervisory authorities take increased measures and the fight begins again. This confrontation encourages the appearance of financial innovations (as a way to avoid restrictions), and also explains the process of innovation in the financial system. The benefits of regulatory measures, in terms of their costs, are difficult to measure, since the benefits are often short-term, while the costs are very long-term.

The experience of the 2007-2009 financial crisis showed that there is a relationship between the compensation structure of financial firms and excessive risk taking by their employees. The main problem was that modern banks tend to reward managers for carrying out risky strategies, but do not charge penalties for making decisions that lead to bank failures, destruction of the financial system and government injections, as well as taxpayer losses. Ethical mistakes and systematic shortcomings in the context of the 2007-2009 financial crisis suggest that the upcoming regulatory dialogue on banking regulatory policy is unlikely to ignore the importance of corporate culture. The problem of the latter in the banking business arose in connection with the resumption of discussions on solving of the two following problems: restoration of public confidence in the banking system and improvement of financial stability.

One of the key areas of formation of risk-based banking supervision and regulation in CEE countries is the introduction of capital requirements. The main reference point in this direction remains the provisions of the Basel Committee of the third Basel Accord, which were published in December 2010 and revised in June 2011. At the level of European countries, it was planned to implement these standards 
during 2013-2019. The implementation consisted of the so-called CRD IV package:

CRR - Capital Requirements Regulation (EU)575/2013.

CRD - Capital Regulation Directive 2013/36/EU - CRDIV.

CRR - this is direct action legislation, that is, this provision is fully implemented and applied in all EU member states, extends the rules that have not been regulated by the CRD IV and relates to Basel Pillar I.

CRD - these are principles and norms that reflect the norms of Basel II and Basel III on capital standards; they are implemented through the adoption of national laws.

The main purpose of these two documents is to strengthen capital requirements as a response to global financial crises, promote the sustainability of financial institutions and the banking sector. The tasks of ensuring the stability and reliability of the banking system should be solved both at the macroeconomic and microeconomic levels. At the macroeconomic level, an important component of economic activity (from the point of view of monetary theory) is the amount of monetary supply in circulation. Other mechanisms that ensure the coordinated functioning of components at the macroeconomics level are interest rates and the volume of bank loans offered. Despite the fact that in the modern economic system, commercial banks are not the only ones who perform the function of financial intermediation in financial markets, their role in this process is still very important. Thus, regulation of banking enables protection of the money supply and gives central banks leverage with which they influence bank reserves, interest rates and lending activities of banks. Socially - the economic nature of banking supervision is to promote banking supervision of the financial system stability, which is achieved through the formation of requirements for banking supervision both by individuals and households (provision of insurance and lending, ensuring the profitability and regularity of the banking system), and by the state through macroeconomic requirements (economic and social protection (laws, rules, national definitions), control over the national system financial policy (macroeconomic policy, creation of an appropriate regulatory environment for banks). The solution of such requirements by banking supervision should be based on the world experience of banking supervision through the involvement of the best methods and practices of banking supervision.

It should be noted that there is no definition of financial stability in the regulatory environment and in particular in EU directives. Economists also do not have a unified approach to its interpretation. However, there are common elements that can be used to understand 
financial stability, namely: safe and well-functioning financial environment, no disturbances or financial instability. From this point of view, everything that helps to make financial structures safer and less susceptible to disturbances is aimed at financial stability. In this sense, it is banking supervision that contributes to achievement of such a goal, because it monitors financial instruments and indicators that are aimed at prevention or solving of problems of financial instability of banks. However, the effectiveness of these instruments should not be overestimated, financial stability cannot be guaranteed, since borrowing against lending is extremely risky for businesses. After all, there can be opportunities for growth only under credit conditions.

\section{Introduction of EU capital standards in Ukraine}

In order to increase the stability of banks in times of financial and economic instability, to create their capital reserves to increase their ability to withstand risks, the National Bank of Ukraine sets requirements for the formation of capital buffers by banks, which were supplemented with a new chapter in accordance with the resolution of the National Bank No. 312 dated May 12, 2015 and comes into force on January 01, 2020, namely: capital reserve (conservation) buffer (planned to be valid from January 01, 2020) and counter-cyclical buffer (by the decision of the regulator). So, it is said that the bank forms capital buffers, namely - a capital reserve (conservation) buffer and a counter-cyclical buffer.

Banks must form capital buffers in excess of the standard value of the fixed capital adequacy ratio (H3). The capital reserve (conservation) buffer is calculated from the total amount of risk. The bank forms a capital reserve (conservation) buffer, starting from:

January 01,2020 - in the amount of $0.625 \%$;

January 01,2021 - in the amount of $1.25 \%$;

January 01,2022 - in the amount of $1.875 \%$;

January 01,2023 - in the amount of $2.5 \%$;

The countercyclical capital buffer is calculated from a total risk of 0 2.5 percent. The size of the counter-cyclical capital buffer is established by a decision of the Board of the National Bank in the event of significant credit activity of banks, considering the risks associated with excessive credit growth. The specified information is posted in advance on the page of the official internet representative office of the National Bank and must contain information, in particular on the size of the buffer and the date of validity of the buffer in the established amount. The main imperatives for the development of the banking supervision system in Ukraine are the Association Agreement between Ukraine and 
the European Union and the Comprehensive Program of Ukrainian Financial Sector Development (Fig. 1.).

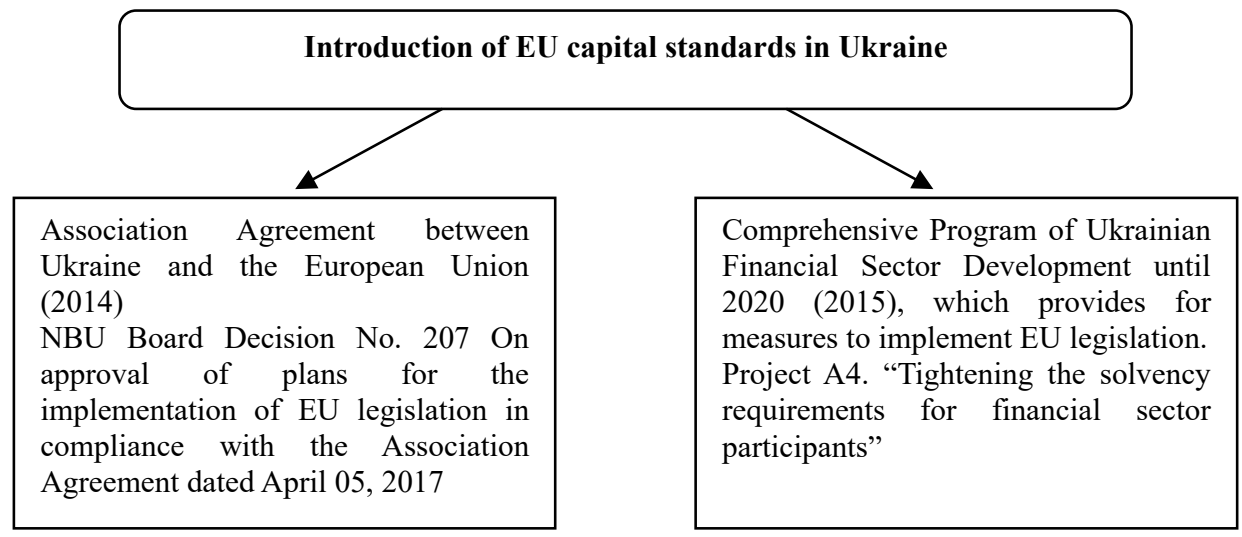

Fig. 1. Introduction of EU capital standards in Ukraine

Comparative characteristics of the capital structures of banks in Ukraine and EU member states are presented in Table 1. As can be seen from the Table 1, there are fundamental differences between the capital structure of EU banks and Ukrainian banks.

The main differences are as follows:

1. Capital structure. In the EU, the share of Tier 1 capital, which plays a key role in maintenance of the bank, has been increased $(75 / 25)$, that is, the ability of banks to absorb losses has been increased. In Ukraine, this indicator is at the level of $50 / 50$ according to the requirements of Basel II. According to NBU Instruction No. 368, Ukraine plans to raise the ratio of Common Equity Capital to Additional Capital starting from January 01, 2019 to the ratio of $70 / 30$. In our opinion, such changes will not affect the overall picture, since there are differences that are more fundamental.

2. According to the legislation of Ukraine, capital is reduced by the amount of only direct investment from the total amount of capital (Common Equity Capital + Additional Capital). In EU countries, according to the norms of the Basel Committee, direct, indirect and synthetic investments are deducted from each corresponding tier of capital, e.i. from both Tier 1 and Tier 2 Capital.

According to experts, Ukraine has strict approaches to capital valuation and instruments. For example, there are no hybrid tools. Moreover, the introduction of the IFRS9 accounting standard is gradually changing the psychology of calculating reserves. The main calculation elements are becoming similar to the Basel standards - 
these are PD and LGD, EAD indicators. The approach for the classification of financial instruments is also changing: instruments that measure depreciation value and instruments that measure fair value. Each of the instruments has a depreciation evaluation based on the credit risk.

Table 1

COMPARATIVE CHARACTERISTICS OF BANKS' CAPITAL STRUCTURES UKRAINE AND EU MEMBER STATES ${ }^{16}$

\begin{tabular}{|c|c|c|c|c|c|}
\hline \multicolumn{3}{|c|}{$\begin{array}{l}\text { Capital structure of Ukrainian banks } \\
\text { (H2> 10\%). The ratio of Common Equity } \\
\text { Capital \& Additional Capital is } 50 / 50\end{array}$} & \multicolumn{3}{|c|}{$\begin{array}{c}\text { Capital structure of EU member states } \\
\text { (minimum value of } 8 \%+\text { conservation buffer } \\
=10.5 \%) \text {. Tier } 1 \text { Capital \& Tier } 2 \text { Capital } \\
\text { ratio is } 75 / 25\end{array}$} \\
\hline \multicolumn{3}{|c|}{1} & \multicolumn{3}{|c|}{2} \\
\hline \multicolumn{3}{|c|}{$\begin{array}{l}\text { 1. Common Equity Tier 1 (CET1). } \\
\text { Components: authorized capital, issue } \\
\text { difference, financial assistance of shareholders, } \\
\text { funds created at the expense of profit } \\
\text { 2. Additional Capital Tier } 2 \text { (AT1). } \\
\text { Components: - previous years' income. } \\
\text { - current year's income reduced by overdue and } \\
\text { non-received > } 30 \text { days accrued income, } \\
\text {-sub-debt. } \\
\text { Capital = Common Equity Capital + } \\
\text { Additional Capital is reduced for direct } \\
\text { investments in other institutions of more than } \\
10 \% \text { and other securities (issued by non-listed } \\
\text { banks that are not in circulation on the stock } \\
\text { exchange), sub-debt. }\end{array}$} & \multicolumn{3}{|c|}{$\begin{array}{l}\text { 1. Tier 1 Capital (CET1 + AT1) } \\
\text { Components: common capital (Common } \\
\text { Shares), share premium on common shares, } \\
\text { retained income, funds (reserve capital and } \\
\text { other capitals) are created at the expense of } \\
\text { profit. } \\
\text { Additional Tier } 1 \text { capital - perpetual capital } \\
\text { instruments, sub-debt (in the event of a } \\
\text { common equity trigger event less than } 5.125 \% \text { ) } \\
\text { is converted into CET1 instruments, or is } \\
\text { written off, } \\
\text { 2. Tier } 2 \text { Capital. Components: authorized } \\
\text { capital (Preferred Shares), share premium on } \\
\text { preferred shares, term capital instruments } \\
\text { (more than } 5 \text { years without incentives for } \\
\text { long-term repayment) }\end{array}$} \\
\hline \multicolumn{3}{|c|}{ NBU capital standards, \% } & \multicolumn{3}{|c|}{ BCBS capital standards, \% } \\
\hline \multicolumn{3}{|c|}{ Instruction No. 368} & Tyne of $s$ & & \\
\hline \multirow{3}{*}{$\begin{array}{l}\text { Type of } \\
\text { capital }\end{array}$} & \multirow{3}{*}{$\begin{array}{l}\text { Existing } \\
\text { standard, \% }\end{array}$} & \multirow{3}{*}{$\begin{array}{l}\text { Planning } \\
\text { standard on } \\
\text { January 01, } \\
2019, \% \\
\end{array}$} & уре о сартыла & II, \% & III, \% \\
\hline & & & Fixed capital, Tier 1 & - & 4.5 \\
\hline & & & Capital Tier 1 & 4 & 6 \\
\hline Capital Tier 1 & 5 & 7 & Capital Tier 2 & 4 & 2 \\
\hline Capital Tier 2 & 5 & 3 & Capital & 8 & 8 \\
\hline Capital & 10 & 10 & Conservation buffer & - & 2.5 \\
\hline
\end{tabular}

${ }^{16}$ Compiled by the authors. 
Table 1 shows the main stages of capital reform - the EU member states introduced a conservation buffer (0.625\%) from January 01, 2016, with a gradual increase to $2.5 \%$ as of January 01,2019 . In Ukraine, the conservation buffer in accordance with Instruction No. 368 will be activated from 0January 1,2020 at the level of 0.625 .

The legislation of Ukraine and regulatory acts of the National Bank of Ukraine do not provide for the use of AT1 instruments in the event of a trigger event. A trigger event is a decrease in the sufficiency index of CET 1 below $5.125 \%$, or another value (over $5.125 \%$ ), which is defined by the bank in the relevant provisions and agreements. In EU countries, AT1 includes perpetual instruments, the main amount of which must be debited or converted to CET1 instruments when a trigger event occurs. After the 2008 crisis, central European countries (Great Britain, Switzerland) began to use such tools.

On June 03, 2016, the Board of the National Bank of Ukraine adopted Resolution No. 338, which amended the instruction on the procedure for regulating the activities of banks in Ukraine, approved by Resolution No. 368 of the NBU Board dated August 28, 2001. These amendments define the procedure for including shareholders' financial assistance in the regulatory capital of a bank. Thus, financial assistance of shareholders is included in the common equity of the bank on the basis of the permission of the National Bank of Ukraine, provided that the funds received in cash and are irrevocable, are not credit, and that the bank's ownership structure meets the requirements for its transparency established by the National Bank of Ukraine. In addition, the calculation of certain economic standards in terms of reduction of the amount of credit risk by the amount of acceptable collateral has been clarified ${ }^{17}$.

\section{Comparative characteristics of elements of the macroprudential policy of Ukraine and the EU member states}

According to the Instruction on regulation of banks in Ukraine, to measure liquidity risk, Ukrainian banks use the structure of assets and liabilities, which is built considering the terms of the transaction for each currency. There is created a cash flow calendar to assess liquidity risk - a schedule of payments for interest and the principal amount of debt. It is similar to the revaluation calendar used to control interest rate risk, with the exception that in the latter the main value is the date of price change, in the cash flow calendar the emphasis is on the date of interest payment and the principal amount of debt. In order to monitor the state of banks

\footnotetext{
${ }^{17}$ On approval of the Instruction on the procedure for regulating the activities of banks in Ukraine: Resolution of the NBU No. 368. 2001. URL: http://zakon2.rada.gov.ua/laws/show/z0841-01. [In Ukrainian].
} 
liquidity the National Bank sets liquidity standards: instant liquidity (H4), current liquidity (H5) and short-term liquidity (H6).

The instant liquidity standard (H4) is defined as the ratio of highly liquid assets to current liabilities of a bank. This standard sets the minimum required amount of highly liquid assets to ensure the fulfillment of current liabilities within one business day and is calculated considering the balance of correspondent accounts opened with other banks and correspondent accounts of other banks.

The instant liquidity standard is defined as the ratio of highly liquid assets to the bank's current liabilities, i.e. it sets the minimum required amount of highly liquid assets to ensure the fulfillment of current liabilities within one business day. This indicator is calculated considering the balance of correspondent accounts opened with other banks and correspondent accounts of other banks.

The current liquidity standard (H5) is defined as the ratio of assets with a final maturity of up to 31 days (inclusive) to the bank's liabilities with a final maturity of up to 31 days (inclusive). This standard sets the minimum required amount of assets of the bank to ensure the fulfillment of the current volume of liabilities within one calendar month and is calculated taking into account the balance of funds placed and raised on correspondent accounts opened with other banks, and on correspondent accounts of other banks and on interbank loans/deposits placed with other banks and received from other banks.

The short-term liquidity standard (H6) is defined as the ratio of assets to liabilities with a final maturity of up to one year. This standard sets the minimum required amount of assets to ensure the fulfillment of their liabilities for one year and is calculated considering the balance of funds placed and raised: for correspondent accounts opened with other banks and correspondent accounts of other banks; for interbank loans/deposits placed with other banks and received from other banks. It should be noted that these indicators did not change or reform radically, although the banking system went through crises that were related to liquidity. The new capital requirements for banks were approved by the NBU Board Resolution No. 312 "On Approval of Amendments to the Instruction on the Procedure for Regulating the Activities of Banks in Ukraine" dated May 12, 2915. According to the Instruction, the minimum regulatory capital of a bank ( $\mathrm{H} 1)$ that received a banking license before July 11, 2014 should be UAH 120 million - before June 17, 2016 and UAH 200 million - from July 11, 2017.

The Instruction also sets out the regulatory capital sufficiency (adequacy) standard (H2), which reflects the bank's ability timely and in full to settle its liabilities. The higher the value of the regulatory capital adequacy standard, the greater the share of risk assumed by the 
bank's owners and the smaller the share of risk of the bank's creditors/depositors. The value of $\mathrm{H} 2$ is defined as the ratio of regulatory capital and risk-weighted ratios of total assets and offbalance sheet instruments.

The normative value of the $\mathrm{H} 2$ coefficient for existing banks must be at least $10 \%$. For banks starting operations, this standard should be: a) during the first 12 months of activity from the date of obtaining the license - not less than $15 \%$; b) during the next 12 months - not less than $12 \%$; c) in the future - not less than $10 \%$.

Common equity adequacy standard (H3) is defined as the ratio of common equity to the sum of assets and off-balance sheet liabilities, weighted by the relevant credit risk ratios. The normative value of the H3 standard must be at least 7 percent.

The main reason for the global crisis of 2008-2009 was the underestimation of banks' liquidity risks. In order to overcome and prevent these risks, the EU, together with the Basel Committee, has developed standards that have helped to overcome these problems Basel III and the CRR and CRD

Directives $^{18}$. Until 2008, macroeconomic policy was not used in Ukraine's financial policy, unlike in Central Europe, where, for example, in the United Kingdom, the first review of financial stability was published in 1996. Therefore, in 2015, the Council and the Financial Stability Committee were established in Ukraine, and in 2016 the first Report "On the State of the Financial System of Ukraine" was published. It is well-known, that the European Council identified the main elements of macroprudential policy on the basis of systemic risks back in 2008-2009 (Fig. 2.).

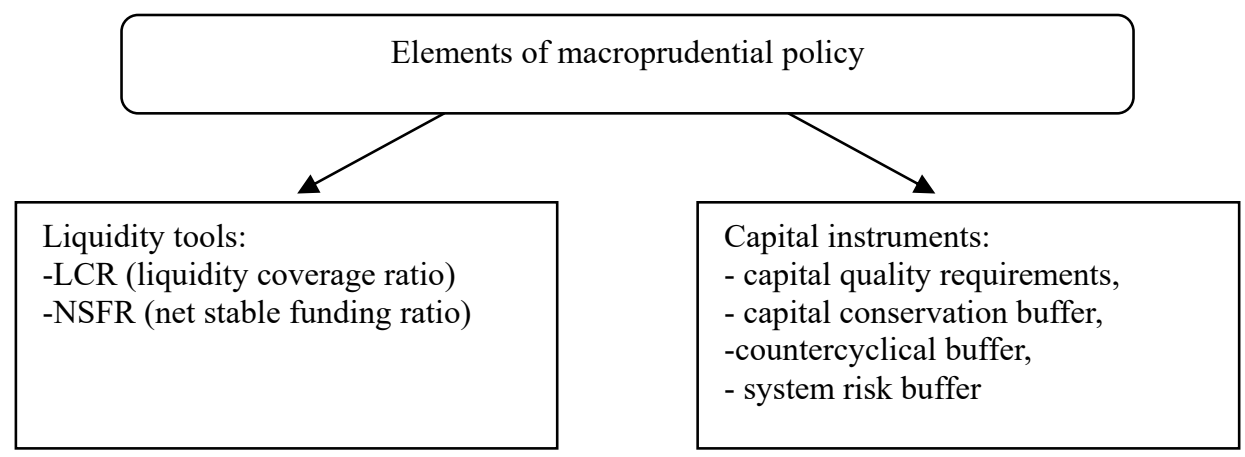

Fig. 5.2. The main elements of macroprudential policy ${ }^{19}$

\footnotetext{
${ }_{18}$ Principles for sound stress testing practices and supervision / Basel Committee on Banking Supervision. 2009. URL: http://www.bis.org/publ/bcbs155.pdf.

${ }^{19}$ Compiled by the author on the basis of BCBS materials.
} 
The introduction of these instruments in Central European countries was quite problematic because, for example, the deficit of highly liquid assets for LCR amounted to EUR 1.7 trillion, and for stable financing - EUR 2.9 trillion $^{20}$. Nevertheless, after the crisis, the share of highly liquid assets in internationally active banks increased. BCBS published their conclusions in 2016, 6 years after the launch of these instruments, which are important for the Ukrainian banking system. These conclusions are as follows:

1. It is more difficult for retail banks to meet LCR requirements and it is more difficult for investment banks to meet NSFR requirements.

2. LCR is sensitive to assumptions as opposed to NSFR.

3. In pursuit of a high LCR, the bank can worsen its risk profile.

4. Meeting LCR requirements does not guarantee banks' resistance to liquidity disturbances.

\section{Conclusions}

Banking regulation is the process of promoting financial stability through the use of special methods, tools, by establishment of specific rules and instructions. Therefore, the functions of banking regulation are closely related to the implementation of monetary policy and the organization of the settlement system and historically carried out by central banks. Supranational banking regulation is a regulatory process carried out by international world-class organizations (International Monetary Fund, International Bank for Reconstruction and Development, European Bank for Reconstruction and Development, Basel Committee on Banking Supervision).

Banking supervision is the control over the stability and sustainability of the banking system, which must adequately respond to global trends and reassess supervisory policy. From the point of view of methodology, banking supervision should be understood as a set of methods, techniques, tools used by banking supervisors to monitor the performance of banks, the application of measures of influence and etc. Banking supervision is based on ongoing analytical review of banks and serves social and economic needs, as there is a close relationship between risk analysis and banking supervision. In Western and domestic scientific sources, the issue of banking supervision is often identified with the analysis of the causes of banking risks and methods of their study. Analysis of the literature

\footnotetext{
${ }^{20}$ Final Report of the IIF Committee on Market Best Practices: Principles of Conduct and Best Practice Recommendations / Institute of International Finance. 2008. URL: https://www.iif.com/system/files/ iif_final_report_of_the_committee_on_market_best_practices.pdf.
} 
has shown that the study of risks has a long history, but the active study of financial risks began relatively recently, namely in the late nineteenth - early twentieth centuries.

Liquidity monitoring tools - stress testing, liability concentration analysis and GAP - analysis (liquidity gaps) are important for the formation of risk-based banking supervision. In Ukraine, the current liquidity ratios are quite static and do not meet the requirements of the Basel Committee. The NBU plans to introduce LCR from 2018 in test calculation mode (without requirements). In developing the LCR, the NBU considers the requirements of Basel and national characteristics the underdeveloped market of securities and highly liquid deposit assets (there are no quality corporate bonds and mortgage bonds). This is taken into account in the components of the liquidity buffer. The NBU took into account the stress scenario of 2014, i.e. higher outflow coefficients for retail and corporate deposits, than the one provided by the Basel Committee.

According to the Comprehensive Action Plan for the implementation of the Financial Development Program in Ukraine, it is planned to improve the systems of regulation and supervision of the financial sector, to continue the transition from compliance based supervision to risk based supervision and oversight, the principles of continuous preemptive monitoring (from April 01, 2015 to December 31, 2016), as well as the introduction of new capital requirements for banks in accordance with the principles of Basel III and EU requirements (from January 01, 2015 to December 31, 2019). Implementation of these measures is possible only through compliance with the requirements of the European Parliament and the Council of Europe, which aim to create equal competition conditions in the financial sector, strengthen the solvency and liquidity requirements of financial sector participants, introduce special requirements for capital, liquidity and other financial institutions, improve the system of regulation and supervision of the financial sector.

In accordance with international principles, an effective banking supervision system should have specific responsibilities and objectives, operational independence, transparency, reliability, and resource base. Therefore, the implementation of these principles into the work of the national banking system is very relevant. Currently, the analysis of the current state of the banking sector and the main regulatory aspects shows that there are problems that indicate the crisis in the banking system of Ukraine, in particular in the system of banking regulation and supervision. Thus, according to the regulatory framework, banking supervision in the system of the National Bank of Ukraine has a sufficient level of independence, but during the financial crisis the 
problematic issues concerning its functional and institutional component were outlined.

\section{References}

1. Banking supervision: textbook (ukr. Bankivskyi naglyad) / Mishchenko V. et al. Kyiv, 2004. - pp. 47-48. [In Ukrainian].

2. Bцrner C.J. Treu und redlich? Eine explorative Bewertung qualitativer Bankenregulierung. Rektor der der Heinrich-Heine-Universitat Dьsseldorf (Hrsg.): Jahrbuch 2003. Duisburg, 2003. p. 335-352.

3. Evolving Banking Regulation. KPMG International. 2015. URL: www.kpmg.com.

4. Final Report of the IIF Committee on Market Best Practices: Principles of Conduct and Best Practice Recommendations / Institute of International Finance. 2008. URL:https:/ /www.iif.com/system/files /iif_final_report_of_the_committee_on market_best_practices.pdf.

5. Global Banking Regulation \& Supervision: What Are the Issues and What Are the Practices? J. Barth, J. Gan, D. Nolle. 2003. URL: http:/ / www.ckgsb.edu.cn /Userfiles / doc/BARTHnolle\%20gan_bood.pdf.

6. Grbning H. Analysis of banking risks. System for assessing corporate governance and financial risk management / transl. from English. Moscow: Ves mir, 2007. - 304 p. [In Russian].

7. Haentjens M. European Banking and Financial Law / M. Haentjens, P. de Gioia-Carabellese. - Abingdon: Routledge, Taylor \& Francis Group, 2015. 800 c. - (Routledge, Taylor \& Francis Group).

8. Herring R. J., Carmassi J. The Structure of Cross-Sector Financial Supervision. Financial Markets, Institutions \& Instruments. 2008. No. 1. p. 51-76.

9. IMF Annual Report: Our Connected World. URL: www.imf.org/external/index.htm.

10. Neuberger D. Mikroцkonomik der Bank. Mьnchen: Verlag Vahlen, 1998. $240 \mathrm{p}$.

11. Putnis J. The banking regulation review. London: The Lawreviews, 2017. $633 \mathrm{c.}$

12. On the National Bank of Ukraine: Law of Ukraine of May 20, 1999 No. 679-XIV. Information of the Verkhovna Rada of Ukraine. 1999. p. 238. [In Ukrainian].

13. On banks and banking activity: Law of Ukraine of December 7, 2000 No. 2121-III. Information of the Verkhovna Rada of Ukraine. 2001. - p. 30. [In Ukrainian].

14. Principles for sound stress testing practices and supervision / Basel $\begin{array}{llll}\text { Committee on Banking Supervision. } & \text { 2009. SRL: }\end{array}$ http://www.bis.org/publ/bcbs155.pdf

15. Principles for Sound Liquidity Risk Management and Supervision / Basel $\begin{array}{llll}\text { Committee on Banking Supervision. } & \text { 2008. }\end{array}$ http://www.bis.org/publ/bcbs144.htm. 
16. Stress Testing by Large Financial Institutions: Current Practice and Aggregation Issues $/$ Bank for international settlement. 2000. URL: http://www.bis.org/publ/cgfs14.htm.

17. Third Basel Accord.- URL: http://www. bis.org.

18. Timothy W.Koch, MacDonald S.Scott. Bank management/W.K. Timothy,S.S.MacDonald.-USA: Thomson Higher Education,2006.-562 p.

19. Wymeersh E. The structure of financial supervision in Europe: About single, twin peaks and multiple financial supervisors. European Business Organization Law Review. 2006. №8. p. 237-306.

The article was received by the Editorial Board on February 26, 2020. 